\title{
Pogranicze jako kategoria w naukach o polityce
}

Janusz Ruszkowski ${ }^{1}$

Link do artykułu:

http://pogranicze.uni.opole.pl/biblioteka/docs/nr1/ruszkowski_nr1.pdf

Standard cytowania (APA):

Ruszkowski, J. (2013). Pogranicze jako kategoria w naukach o polityce. Pogranicze. Polish Borderlands Studies, $n r$ 1, s. 78-79.

Granica jako główny element konstytutywny terminu „pogranicze” oraz jako wyznacznik zwierzchnictwa państwa (domeny) nad danym obszarem, posiada przede wszystkim polityczne znaczenie, a co za tym idzie jest przedmiotem refleksji politologicznej. Tego faktu nie jest w stanie zmienić zauważalny (przede wszystkim w Unii Europejskiej) zanik oddzielającej czy separującej funkcji granicy i pojawienie się koncepcji bliskich etnopluralizmowi lub multikulturowemu współżyciu (Ruszkowski 1997).

„Pogranicze” w elementarnym ujęciu statycznym składa się z regionu granicznego (czyli położonego na styku granicy) $\mathrm{w}$ jednym państwie. Z kolei w ujęciu dynamicznym „pogranicze" tworzą regiony graniczne usytuowane po obu stronach granicy i należące do dwóch różnych państw, co w efekcie staje się zalążkiem współpracy transgranicznej tworzącej istotne pole zainteresowania badaczy w naukach o polityce oraz w studiach europejskich. „Pogranicze” jako obszar stykowy oraz przejściowy staje się więc rodzajem pomostu, gdyż pozwala na przenikanie się różnorodnych kontaktów przekraczających granicę (Żurek 2011). „Pogranicza” są zatem mikrolaboratoriami procesów pomostowych, w tym integracyjnych, są więc zalążkami kontaktów międzynarodowych. To właśnie „pogranicza” są obszarami licznych politycznych, ekonomicznych, społecznych i kulturowych: operacji, transakcji, negocjacji, deliberacji, koordynacji, instytucjonalizacji itd. Stąd też integracja europejska jawi się jako definiowana przez procesy zachodzące na pograniczach (takie jak: inkluzja, wykluczenie, wzajemne wpływy, transnarodowość, różnorodność językowa, współzależność, spójność itp.).

W konsekwencji wykazanych powiązań badawczych, „pogranicze” jest kategorią należącą do siatki pojęć w naukach o polityce. Bardziej pluralistyczne podejścia sytuują kategorię ,pogranicza” jako jedną z elementarnych kategorii wchodzących w skład relatywnie młodej subdyscypliny $\mathrm{w}$ naukach o polityce nazywaną border studies. Obecnie - także w Polsce trwa faza teoretycznej refleksji i metodologicznych aplikacji w ramach border studies. (Jańczak 2008; 2009; 2011; Ruszkowski 1997; Żurek 2011) Warto zauważyć, że obok tak klasycznych terminów jak ,pogranicze”, „współpraca transgraniczna”, czy współpraca euroregionalna", pojawiają się bardziej zaawansowane sekwencje badawcze poświęcone cross-border governance (CBG), multi-level network (MLN), multi-level links (MLL), czy też ponadgraniczności (suprabordering).

$\overline{1}$ Prof. zw. dr hab. Janusz Ruszkowski: dyrektor Instytutu Politologii i Europeistyki Uniwersytetu Szczecińskiego. 
Reasumując, choć termin „pogranicze" często pojawia się jako jednostka analityczna w studiach europejskich, czy w border studies, to należy pamiętać, że oba wymienione obszary badawcze są subdyscyplinami w ramach nauk o polityce, stąd politologiczna proweniencja „pogranicza” nie powinna budzić wątpliwości.

\section{Literatura:}

Jańczak, J. (2009). Cross-border governance jako koncepcja wspólnego zarządzania miastem podzielonym. Efektywność w warunkach członkostwa w UE. W: J. Jańczak, M. Musiał-Karg (red.), Pogranicze polsko-niemieckie po 2004 roku. Nowa jakość sąsiedztwa? Toruń: Wydawnictwo Adam Marszałek.

Jańczak, J. (2008). Cross-border governance jako podstawa zaawansowanej współpracy polsko-niemieckiej w regionach przygranicznych. W: J. Jartyś, A. Staszczyk (red.), Polityka Sasiedztwa Unii Europejskiej. Pomostowość, czy buforowość, Szczecin: Instytut Politologii i Europeistyki Uniwersytetu Szczecińskiego.

Jańczak, J., (red.). (2011). De-Bordering, Re-Bordering and Symbols on the European Boundaries. Berlin: Logos Verlag.

Ruszkowski, J. (1997). Metodologiczne aspekty badań na pograniczem polsko-niemieckim. Acta Politica, $n r$ 8, s. 19-30.

Żurek, M. (2011). Teoria wspótpracy transgranicznej na przykładzie Euroregionu Pomerania. Szczecin: Instytut Politologii i Europeistyki Uniwersytetu Szczecińskiego. 